\title{
Effects of complete whey-protein breakfasts versus whey without GMP-breakfasts on energy intake and satiety.
}

Citation for published version (APA):

Veldhorst, M. A. B., Nieuwenhuizen, A. G., Hochstenbach-Waelen, A., Westerterp, K. R., Engelen, M. P., Brummer, R. J. M., Deutz, N. E., \& Westerterp-Plantenga, M. S. (2009). Effects of complete whey-protein breakfasts versus whey without GMP-breakfasts on energy intake and satiety. Appetite, 52(2), 388-395. https://doi.org/10.1016/j.appet.2008.11.014

Document status and date:

Published: 01/01/2009

DOI:

10.1016/j.appet.2008.11.014

Document Version:

Publisher's PDF, also known as Version of record

\section{Document license:}

Taverne

\section{Please check the document version of this publication:}

- A submitted manuscript is the version of the article upon submission and before peer-review. There can be important differences between the submitted version and the official published version of record.

People interested in the research are advised to contact the author for the final version of the publication, or visit the DOI to the publisher's website.

- The final author version and the galley proof are versions of the publication after peer review.

- The final published version features the final layout of the paper including the volume, issue and page numbers.

Link to publication

\footnotetext{
General rights rights.

- You may freely distribute the URL identifying the publication in the public portal. please follow below link for the End User Agreement:

www.umlib.nl/taverne-license

Take down policy

If you believe that this document breaches copyright please contact us at:

repository@maastrichtuniversity.nl

providing details and we will investigate your claim.
}

Copyright and moral rights for the publications made accessible in the public portal are retained by the authors and/or other copyright owners and it is a condition of accessing publications that users recognise and abide by the legal requirements associated with these

- Users may download and print one copy of any publication from the public portal for the purpose of private study or research.

- You may not further distribute the material or use it for any profit-making activity or commercial gain

If the publication is distributed under the terms of Article $25 \mathrm{fa}$ of the Dutch Copyright Act, indicated by the "Taverne" license above, 
Research report

\title{
Effects of complete whey-protein breakfasts versus whey without GMP-breakfasts on energy intake and satiety
}

\author{
Margriet A.B. Veldhorst ${ }^{\mathrm{a}, \mathrm{c}, *}$, Arie G. Nieuwenhuizen ${ }^{\mathrm{a}, \mathrm{c}}$, Ananda Hochstenbach-Waelen ${ }^{\mathrm{a}, \mathrm{c}}$, \\ Klaas R. Westerterp ${ }^{\mathrm{a}, \mathrm{c}}$, Marielle P.K.J. Engelen ${ }^{\mathrm{b}}$, Robert-Jan M. Brummer ${ }^{\mathrm{c}}$, Nicolaas E.P. Deutz ${ }^{\mathrm{b}, \mathrm{c}}$, \\ Margriet S. Westerterp-Plantenga ${ }^{\mathrm{a}, \mathrm{c}}$ \\ ${ }^{a}$ Dept. of Human Biology, Nutrition and Toxicology Research Institute Maastricht (NUTRIM), Maastricht University, P.O. Box 616, 6200 MD, Maastricht, The Netherlands \\ ${ }^{\mathrm{b}}$ Dept. of Surgery, Nutrition and Toxicology Research Institute Maastricht (NUTRIM), Maastricht University, P.O. Box 616, 6200 MD, Maastricht, The Netherlands \\ ${ }^{\mathrm{c}}$ Top Institute Food and Nutrition, P.O. Box 557, 6700 AN Wageningen, The Netherlands
}

\section{A R T I C L E I N F O}

\section{Article history:}

Received 8 July 2008

Received in revised form 21 November 2008

Accepted 26 November 2008

\section{Keywords:}

Satiety

Energy intake

Whey-protein

Glycomacropeptide (GMP)

Amino acids

\begin{abstract}
A B S T R A C T
Aim: To compare the effects of whey versus whey without glycomacropeptide (GMP) in a high and a normal amount of protein in a breakfast custard on satiety and energy intake (EI), taking concentrations of amino acids (AA), glucose, insulin, glucagon-like peptide 1 (GLP-1) and ghrelin into account. Methods: Twenty-five healthy subjects (mean \pm S.E.M., BMI: $23.9 \pm 0.3 \mathrm{~kg} / \mathrm{m}^{2}$; age: $22 \pm 1$ years) received a breakfast containing whey or whey without GMP as protein type with $10 / 55 / 35$ or $25 / 55 / 20$ En\% protein/ carbohydrate/fat in a randomized, single-blind design. Appetite profile (Visual Analogue Scale, VAS), glucose, insulin, GLP-1, ghrelin and AA concentrations were measured, and the adequate moment for ad libitum lunch was determined based on differences in ghrelin concentration. In a second set of experiments subjects received the same breakfasts; ad libitum lunch was offered at the pre-determined moment. Results: After a breakfast with $25 \mathrm{En} \%$ protein increases in insulin and GLP-1 and decreases in ghrelin concentrations were larger; increases in satiety ratings were lower than after $10 \mathrm{En} \%(p<0.05)$; there was a treatment $\times$ time interaction effect on glucose and insulin concentrations $(p<0.001)$. After a breakfast with whey without GMP insulin concentrations were increased more than after whey $(p<0.05)$. EI at lunch was lower after whey than after whey without GMP $(2877 \pm 165 \mathrm{~kJ}$ versus $3208 \pm 178 \mathrm{~kJ}, p<0.05)$, coinciding with more increased concentrations of serine, threonine, alanine, alpha-aminobutyric acid and isoleucine $(p<0.05)$. Conclusion: GMP as a whey-fraction reduced energy intake coinciding with increased concentrations of certain amino acids, irrespective of the concentration of whey-protein. Although between different concentrations of whey-protein differences in hormone responses were observed, these were unrelated to satiety ratings or energy intake.
\end{abstract}

(c) 2008 Elsevier Ltd. All rights reserved.

\section{Introduction}

The increasing incidence of obesity is considered to be a major health problem because it is associated with a number of diseases, including diabetes mellitus type 2, cardiovascular disease and certain types of cancer (Pi-Sunyer, 1993; Seidell, 1995). Obesity is the result of a positive energy balance, which arises when energy intake exceeds energy expenditure. The control of body weight involves several pathways, so weight management requires a multi-factorial approach (Westerterp-Plantenga et al., 2006). Recent findings suggest that a relatively high protein intake plays

\footnotetext{
* Corresponding author at: Maastricht University, Human Biology, P.O. Box 616, 6200 MD Maastricht, The Netherlands.

E-mail address: m.veldhorst@hb.unimaas.nl (Margriet A.B. Veldhorst).
}

a role in food intake regulation and body weight regulation. A high protein diet has been suggested to increase postprandial and postabsorptive satiety, decrease food intake and preserve a fat-free body mass thereby sustaining energy expenditure (Lejeune, Kovacs, \& Westerterp-Plantenga, 2005; Skov, Toubro, Ronn, Holm, \& Astrup, 1999; Weigle et al., 2005; Westerterp-Plantenga et al., 2006). The importance of satiety particularly appears from a study by Weigle et al., in which a high protein diet reduced ad libitum food intake while sustaining satiety at a comfortable level during a 12-week period (Weigle et al., 2005). In order to assess the satiating potential of whey-protein in particular, the present study focuses on short-term energy intake and satiety.

Milk protein consists of $\sim 20 \%$ of whey-protein which is considered to be a relatively 'fast' protein, i.e. digested and absorbed rapidly (Boirie et al., 1997; Dangin et al., 2001; Dangin, Boirie, Guillet, \& Beaufrere, 2002; Hall, Millward, Long, \& Morgan, 
2003; Morifuji, Sakai, \& Sugiura, 2005). Whey-protein has been shown to reduce short-term energy intake and affect satiety relative to placebo, carbohydrate and other proteins (Luhovyy, Akhavan, \& Anderson, 2007). Whey-protein includes beta-lactoglobulin, alpha-lactalbumin and glycomacropeptide (GMP) (Marshall, 2004). GMP has many biological activities and has been suggested to affect food intake regulation (Brody, 2000; Gustafson, McMahon, Morrey, \& Nan, 2001; Luhovyy et al., 2007; Pedersen et al., 2000; Yvon, Beucher, Guilloteau, Le Huerou-Luron, \& Corring, 1994). We therefore investigated whether whey would influence satiety and subsequent energy intake to a larger extend than whey where GMP was removed, referred to as whey and whey without GMP, respectively.

The comparison of effects on food intake from whey and whey without GMP was executed at two different concentrations of whey-protein, as the only protein in the food matrix. The wheyprotein was offered in a breakfast custard consisting of $20 \%$ of the subject-specific daily energy requirements, with amounts of wheyprotein that represent the highest recommended protein intake per day, i.e. $25 \%$ of energy from protein, versus the lowest normal protein intake per day, i.e. 10\% of energy from protein (Spaaij \& Pijls, 2004).

The aim of the study was to compare the effects of whey versus whey without GMP in a high and a normal amount of protein offered in a breakfast on energy intake and satiety, taking plasma amino acid concentrations, appetite ratings, and concentrations of glucose, insulin, glucagon-like peptide 1 (GLP-1) and ghrelin into account.

\section{Subjects and methods}

\section{Subjects}

A power calculation, based on the results of Anderson et al., where a difference in energy intake of $791 \mathrm{~kJ}$ was observed after a preload with whey-protein compared with control (Anderson, Tecimer, Shah, \& Zafar, 2004), revealed that a sample size of 25 subjects was needed to be able to determine differences in ad libitum energy intake. Thirty healthy male and female volunteers (body mass index $22-30 \mathrm{~kg} / \mathrm{m}^{2}$, age $18-40$ years) were recruited by advertisements in local newspapers and on notice boards at the university. They underwent a screening procedure including medical history taking, measurement of body weight and height and cognitive restrained eating using a Dutch translation of the Three Factor Eating Questionnaire (TFEQ) (Stunkard \& Messick, 1985; Westerterp-Plantenga, Westerterp et al., 1999). Twenty-five subjects (11 males and 14 females) were selected on the basis of being in good health, non-smokers, non-vegetarian, not cognitively dietary restraint (TFEQ Factor 1 score $\leq 9$ ), not using medication apart from oral contraceptives and at most moderate alcohol users ( $\leq 10$ alcoholic consumptions per week). Their mean age was $22 \pm 1$ years, and their body weight was $74.4 \pm 1.8 \mathrm{~kg}$ (BMI: $23.9 \pm 0.3 \mathrm{~kg} / \mathrm{m}^{2}$ ). Five volunteers were not selected because being a vegetarian, smoking or consuming $>10$ alcoholic consumptions per week (one, two and two volunteers, respectively). Written informed consent was obtained from the participants and the study protocol was approved by the Medical Ethics Committee of the University Hospital Maastricht.

\section{Study design}

A randomized, single-blind, $2 \times 2$ Latin square design was used. All subjects came to the university on four occasions, separated by at least 1 week. On each test day, subjects received one of the four types of the subject-specific standardized custard breakfast and appetite ratings and blood parameters were obtained. This first part of the study was used in order to determine the moment in time for the subsequent ad libitum test meal to be able to show a possible difference in food intake. The adequate moment in time to offer lunch was determined by the latest time point after breakfast where there still were statistically significant differences in the concentrations of the orexigenic hormone ghrelin.

The results of the first part of the study showed that ghrelin concentrations were different at $180 \mathrm{~min}$ after breakfast $(0.87 \pm 1.01 \mathrm{pmol} / \mathrm{l}$ versus $-2.78 \pm 1.07 \mathrm{pmol} / \mathrm{l}, p<0.05$, after whey without GMP $10 \%$ and whey without GMP $25 \%$, respectively), therefore this moment in time was chosen to offer the ad libitum lunch in the second set of experiments.

After 2 months, subjects again came to the university four times in a randomized, single-blind, $2 \times 2$ Latin square design, separated by at least 1 week. On each test day subjects again received one of the four types of the subject-specific standardized custard breakfast and stayed in the laboratory till ad libitum lunch was offered at $180 \mathrm{~min}$ after breakfast, being the previously determined moment in time.

\section{Breakfast}

Breakfast was offered as a custard, with whey or whey without GMP (whey, Ultra Whey 90, Volactive Functional Food Products, Orwell, United Kingdom; whey without GMP, WPC 80, DMV International, Veghel, The Netherlands) as a single protein source, with either protein/carbohydrate/fat: 10/55/35 En\% (normal protein) or protein/carbohydrate/fat: 25/55/20 En\% (high protein). Protein was exchanged with fat; carbohydrate content was kept constant because of its effect on protein metabolism (Munro, 1976). The four custards all had an energy density of $4 \mathrm{~kJ} / \mathrm{g}$. The breakfast contained $20 \%$ of daily energy requirements, calculated as basal metabolic rate (BMR), according to the equation of HarrisBenedict, multiplied by an activity index of 1.75 which is the average value reported for the general population in the Netherlands (Harris \& Benedict, 1918; Westerterp \& Kester, 2003). The mean energy content of the breakfast was $2.52 \pm 0.07 \mathrm{MJ}$ and the provided breakfasts had to be and actually were completely finished within 15 min.

The custards were produced by NIZO Food Research bv. (Ede, The Netherlands) and had tapioca starch (Farinex VA50T, AVEBE, Veendam, The Netherlands and Perfectamyl 3108 AVEBE, Veendam, The Netherlands) and sunflower oil (Reddy, NV Vandemoortele, Roosendaal, The Netherlands) as the carbohydrate and fat sources and were citrus-vanilla (citrus, J.B. de lange, Belfeld, The Netherlands; vanilla, J.B. de lange, Belfeld, The Netherlands) flavored. Extensive product development and use of a trained taste panel with healthy male and female volunteers lead to custards that did not differ significantly in color, taste or viscosity. The amino acid composition of the custards is presented in Table 1.

\section{Lunch}

According to a normal Dutch lunch consisting of bread and a filling, the ad libitum lunch consisted of Turkish bread ( $400 \mathrm{~g}$ ) with egg salad (400 g) with 13/41/46 En\% protein/carbohydrate/fat with an energy density of $11.4 \mathrm{~kJ} / \mathrm{g}$. Beforehand it was tested whether all subjects liked the lunch sufficiently. Lunch was prepared by the research staff and served as one large Turkish bread with egg salad equally spread over it. Lunch was offered in excess and all subjects were served the same amount of lunch and were instructed to eat till they were comfortably full. None of the subjects finished the offered lunch completely nor asked for more.

\section{Study protocol}

In the first set of experiments the protocol started at 08:00 h after an overnight fast from 22:00 h. A Venflon catheter was placed in a superficial dorsal vein of the hand for blood sampling. To 
Table 1

Amino acid content of the breakfasts given as a custard with either 10 En\% or 25 En\% from whey- or whey without GMP-protein (g amino acids/100 g custard).

\begin{tabular}{|c|c|c|c|c|}
\hline & Whey $10 \%$ & Whey $25 \%$ & Whey without GMP $10 \%$ & Whey without GMP 25\% \\
\hline Glutamic acid $^{\mathrm{a}}$ & 0.381 & 0.957 & 0.378 & 0.922 \\
\hline Aspartic acid ${ }^{\mathrm{b}}$ & 0.230 & 0.579 & 0.252 & 0.615 \\
\hline Cysteine & 0.055 & 0.139 & 0.071 & 0.172 \\
\hline Serine & 0.099 & 0.249 & 0.088 & 0.216 \\
\hline Histidine & 0.039 & 0.097 & 0.047 & 0.115 \\
\hline Glycine & 0.035 & 0.088 & 0.038 & 0.092 \\
\hline Threonine & 0.150 & 0.378 & 0.106 & 0.259 \\
\hline Arginine & 0.055 & 0.139 & 0.067 & 0.164 \\
\hline Alanine & 0.106 & 0.266 & 0.105 & 0.255 \\
\hline Tyrosine & 0.061 & 0.154 & 0.079 & 0.192 \\
\hline Valine & 0.123 & 0.309 & 0.113 & 0.275 \\
\hline Methionine & 0.048 & 0.121 & 0.051 & 0.125 \\
\hline Isoleucine & 0.141 & 0.355 & 0.126 & 0.307 \\
\hline Phenylalanine & 0.062 & 0.156 & 0.078 & 0.189 \\
\hline Tryptophan & 0.039 & 0.099 & 0.050 & 0.123 \\
\hline Leucine & 0.226 & 0.567 & 0.277 & 0.675 \\
\hline Lysine & 0.201 & 0.504 & 0.230 & 0.560 \\
\hline Proline & 0.128 & 0.321 & 0.097 & 0.238 \\
\hline Branched-chain amino acids & 0.490 & 1.232 & 0.515 & 1.257 \\
\hline Large neutral amino acids & 0.592 & 1.487 & 0.643 & 1.570 \\
\hline
\end{tabular}

a Glutamic acid = glutamine + glutamate.

b Aspartic acid = asparagine.

obtain arterialized venous blood samples the hand was placed in a thermostatically controlled hot box at $60^{\circ} \mathrm{C}$ for 20 min before the sampling time. A basal blood sample was taken and appetite ratings were scored. After $5 \mathrm{~min}$ a second basal blood sample was obtained and breakfast was offered ( $t=0 \mathrm{~min})$. After the first and the last bite, taste perception was scored. Appetite ratings were completed just before breakfast and at 20,40,60, 80, 100, 120, 180 and $240 \mathrm{~min}$ after breakfast. Blood samples for urea and amino acid determination were obtained at 5 min and subsequently just after the appetite ratings; blood samples for determination of glucose, insulin and ghrelin concentrations were obtained before and 40 , 60,120 , and 180 min after breakfast, also just after the appetite ratings at those time points. Venous blood samples for determination of GLP-1 concentration were obtained separately before, and at $30,60,90,120$, and $180 \mathrm{~min}$ after breakfast by means of a Venflon catheter placed in an antecubital vein (Adam \& Westerterp-Plantenga, 2005). Subjects were allowed to drink two glasses of water spread over the morning.

In the second set of experiments, the protocol started after an overnight fast from 22:00 h at 8:30 h with scoring appetite ratings. Breakfast was offered ( $t=0 \mathrm{~min})$ and completed within $15 \mathrm{~min}$. Lunch was offered at the previously determined moment in time, 180 min after breakfast. Subjects were allowed to drink three glasses of water spread over the entire test period.

\section{Measurements}

\section{Appetite profile}

To determine the appetite profile, hunger, fullness, satiety and desire to eat were rated on $100 \mathrm{~mm}$ Visual Analogue Scales (VASs), anchored with 'not at all' and 'extremely' during the test day (Stubbs et al., 2000). Subjects were instructed to rate themselves by marking the scale at the point that was most appropriate to their feeling at that time. The distance from the left end of the scale to the mark was measured in $\mathrm{mm}$; changes from baseline $(\Delta)$ were calculated by subtracting the baseline score $(-5 \mathrm{~min})$ from the score at a certain time point.

\section{Taste perception}

Taste perception profiles of the custards were assessed after the first and the last bite of the breakfast using $100 \mathrm{~mm}$ Visual Analogue Scales, anchored with 'not at all' and 'extremely' on the aspects: pleasantness, sweetness, sourness, saltiness, bitterness, savouriness, crispiness and creaminess.

\section{Blood parameters}

Blood was distributed into EDTA tubes for glucose, insulin, and ghrelin measurement. For GLP-1 measurement blood was collected in EDTA tubes with added dipeptidyl peptidase IV inhibitor. For amino acid and urea determination, blood was collected in lithium heparin tubes. Blood samples were centrifuged at $4{ }^{\circ} \mathrm{C}$ for $10 \mathrm{~min}$ at $3000 \mathrm{rpm}$. Hydrochloric acid and phenylmethylsulfonyl fluoride were added to plasma for active ghrelin determination. For amino acid analysis, $250 \mu \mathrm{l}$ plasma was deproteinized by mixing it with $20 \mathrm{mg}$ dry sulfosalicylic acid. For analysis of urea, $200 \mu \mathrm{l}$ plasma was deproteinized by mixing it with $20 \mu \mathrm{l}$ of $500 \mathrm{~g} / \mathrm{l}$ trichloroacetic acid solution. All samples were stored at $-80^{\circ} \mathrm{C}$ until further analysis. Plasma glucose concentrations were determined using the hexokinase method (Glucose HK 125 kit, ABX Diagnostics, Montpellier, France). Insulin concentrations were measured by RIA (Linco Research Inc., St. Charles, MO, USA). Plasma active ghrelin concentrations were measured by ELISA (Linco Research Inc., St. Charles, MO, USA). Plasma active GLP-1 samples were analyzed using ELISA (EGLP-35K; Linco Research Inc., St. Charles, MO, USA). Plasma concentrations of amino acids were determined with the use of a fully automated HPLC (Pharmacia, Woerden, The Netherlands), after precolumn derivatization with o-phthaldialdehyde (van Eijk, Rooyakkers, \& Deutz, 1993). Plasma urea was analyzed spectrophotometrically on a COBAS Mira S (Roche Diagnostica, Hoffman-La Roche, Basel, Switzerland).

\section{Energy intake (EI)}

The food provided for lunch was weighed before and after eating and EI was calculated by multiplying the amount of food consumed by the energy value of the food as indicated by the product labels $(11.4 \mathrm{~kJ} / \mathrm{g})$.

\section{Statistical analysis}

Data are presented as mean changes from baseline \pm standard error to the mean (S.E.M.), unless otherwise indicated (Senn, 2006). The area under the curve (AUC) or the area above the curve (AAC, for ghrelin) of changes from baseline over time was calculated using the trapezoidal method. 
Table 2

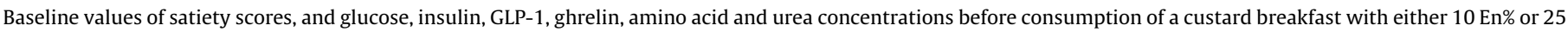
En\% from whey- or whey without GMP-protein in 25 subjects (men and women).

\begin{tabular}{|c|c|c|c|c|}
\hline & Whey $10 \%$ & Whey $25 \%$ & Whey without GMP 10\% & Whey without GMP 25\% \\
\hline Satiety (mmVAS) & $17 \pm 3$ & $19 \pm 4$ & $16 \pm 3$ & $23 \pm 4$ \\
\hline Glucose (mmol/l) & $5.27 \pm 0.11$ & $5.18 \pm 0.06$ & $5.18 \pm 0.07$ & $5.19 \pm 0.07$ \\
\hline Insulin $(\mathrm{mU} / \mathrm{l})$ & $13.76 \pm 0.89$ & $13.41 \pm 0.69$ & $13.01 \pm 0.57$ & $16.93 \pm 2.52$ \\
\hline GLP-1 (pmol/l) & $4.40 \pm 2.69$ & $4.10 \pm 2.59$ & $4.80 \pm 2.79$ & $4.90 \pm 2.80$ \\
\hline Ghrelin (pmol/l) & $7.92 \pm 0.90$ & $10.60 \pm 0.80$ & $9.70 \pm 0.90$ & $9.57 \pm 1.30$ \\
\hline Glutamate $(\mu \mathrm{mol} / \mathrm{l})$ & $105 \pm 4$ & $103 \pm 3$ & $96 \pm 2$ & $104 \pm 2$ \\
\hline Asparagine $(\mu \mathrm{mol} / \mathrm{l})$ & $58 \pm 2$ & $58 \pm 3$ & $55 \pm 2$ & $55 \pm 1$ \\
\hline Serine $(\mu \mathrm{mol} / \mathrm{l})$ & $132 \pm 6$ & $133 \pm 5$ & $132 \pm 6$ & $136 \pm 6$ \\
\hline Glutamine $(\mu \mathrm{mol} / \mathrm{l})$ & $512 \pm 16$ & $511 \pm 11$ & $490 \pm 11$ & $524 \pm 17$ \\
\hline Histidine $(\mu \mathrm{mol} / \mathrm{l})$ & $92 \pm 2$ & $94 \pm 3$ & $95 \pm 4$ & $97 \pm 3$ \\
\hline Glycine $(\mu \mathrm{mol} / \mathrm{l})$ & $231 \pm 13$ & $236 \pm 10$ & $210 \pm 8$ & $226 \pm 11$ \\
\hline Threonine $(\mu \mathrm{mol} / \mathrm{l})$ & $140 \pm 7$ & $147 \pm 8$ & $137 \pm 6$ & $139 \pm 5$ \\
\hline Citrulline $(\mu \mathrm{mol} / \mathrm{l})$ & $30 \pm 1$ & $30 \pm 1$ & $29 \pm 1$ & $30 \pm 1$ \\
\hline Arginine $(\mu \mathrm{mol} / \mathrm{l})$ & $85 \pm 4$ & $86 \pm 3$ & $83 \pm 2$ & $88 \pm 4$ \\
\hline Alanine $(\mu \mathrm{mol} / \mathrm{l})$ & $293 \pm 13$ & $290 \pm 17$ & $283 \pm 9$ & $305 \pm 19$ \\
\hline Taurine $(\mu \mathrm{mol} / \mathrm{l})$ & $32 \pm 1$ & $32 \pm 1$ & $31 \pm 1$ & $32 \pm 1$ \\
\hline Alpha-aminobutyric acid ( $\mu \mathrm{mol} / \mathrm{l})$ & $16 \pm 1$ & $15 \pm 1$ & $16 \pm 1$ & $18 \pm 1$ \\
\hline Tyrosine $(\mu \mathrm{mol} / \mathrm{l})$ & $55 \pm 2$ & $57 \pm 3$ & $52 \pm 2$ & $54 \pm 2$ \\
\hline Valine $(\mu \mathrm{mol} / \mathrm{l})$ & $176 \pm 6$ & $188 \pm 5$ & $172 \pm 4$ & $178 \pm 5$ \\
\hline Methionine $(\mu \mathrm{mol} / \mathrm{l})$ & $24 \pm 1$ & $27 \pm 2$ & $24 \pm 1$ & $25 \pm 1$ \\
\hline Isoleucine $(\mu \mathrm{mol} / \mathrm{l})$ & $96 \pm 26$ & $66 \pm 2$ & $61 \pm 1$ & $67 \pm 2$ \\
\hline Phenylalanine ( $\mu \mathrm{mol} / \mathrm{l})$ & $49 \pm 1$ & $49 \pm 1$ & $48 \pm 1$ & $50 \pm 1$ \\
\hline Tryptophan $(\mu \mathrm{mol} / \mathrm{l})$ & $49 \pm 1$ & $48 \pm 1$ & $47 \pm 1$ & $48 \pm 1$ \\
\hline Leucine $(\mu \mathrm{mol} / \mathrm{l})$ & $113 \pm 4$ & $114 \pm 3$ & $107 \pm 2$ & $113 \pm 3$ \\
\hline Ornithine $(\mu \mathrm{mol} / \mathrm{l})$ & $61 \pm 6$ & $54 \pm 3$ & $52 \pm 2$ & $53 \pm 2$ \\
\hline Lysine $(\mu \mathrm{mol} / \mathrm{l})$ & $152 \pm 6$ & $157 \pm 5$ & $148 \pm 4$ & $151 \pm 4$ \\
\hline Branched-chain amino acids ( $\mu \mathrm{mol} / \mathrm{l})$ & $386 \pm 26$ & $368 \pm 10$ & $340 \pm 7$ & $358 \pm 8$ \\
\hline Large neutral amino acids ( $\mu \mathrm{mol} / \mathrm{l})$ & $490 \pm 26$ & $475 \pm 11$ & $441 \pm 8$ & $463 \pm 10$ \\
\hline Sum amino acids $(\mu \mathrm{mol} / \mathrm{l})$ & $2503 \pm 66$ & $2497 \pm 58$ & $2369 \pm 35$ & $2494 \pm 54$ \\
\hline Urea $(\mathrm{mmol} / \mathrm{l})$ & $3.77 \pm 0.16$ & $4.02 \pm 0.20$ & $3.91 \pm 0.18$ & $3.87 \pm 0.17$ \\
\hline
\end{tabular}

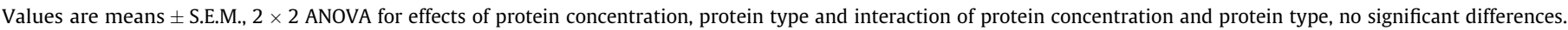

After the first set of experiments, a $2 \times 2$ repeated measures ANOVA was carried out to test for the effects of protein concentration, protein type and interaction between protein concentration and protein type on the AUCs of satiety ratings, glucose, insulin, GLP-1, ghrelin, amino acids and urea concentrations. Moreover, a three-way ANOVA was carried out to test for the effects of protein type, protein concentration, time and interaction between protein concentration, protein type and/or time on satiety ratings, glucose, insulin, GLP-1 and ghrelin. A Fisher's PLSD post hoc correction was used to determine differences between different time points. Since changes in ghrelin concentration were used to determine the moment in time to offer lunch, an ANOVA repeated measures per time point was used to assess possible differences between the different breakfasts at each time point.

After the second set of experiments, again a $2 \times 2$ repeated measures ANOVA was carried out to test for the effects of protein concentration, protein type and interaction between protein concentration and protein type on energy intake at lunch. A pvalue $<0.05$ was regarded as statistically significant. Statistical procedures were performed using StatView 5.0 (SAS Institute Inc., USA, 1998).

\section{Results}

Baseline satiety ratings and concentrations of glucose, insulin, GLP-1, ghrelin, amino acids or urea were not different between treatments (Table 2).

\section{Taste perception}

The pleasantness of taste of the breakfasts was $59 \pm 3$ mmVAS for the whey $10 \%$ breakfast, $67 \pm 4 \mathrm{mmVAS}$ for the whey $25 \%$ breakfast, $53 \pm 4$ mmVAS for the whey without GMP 10\% breakfast, and $58 \pm 3$ mmVAS for the whey without GMP 25\% breakfast (ns).

\section{Satiety}

There was no interaction effect of protein concentration $\times$ protein type on the satiety response expressed as AUC and there were no effects of protein concentration or protein type on the AUC of satiety.

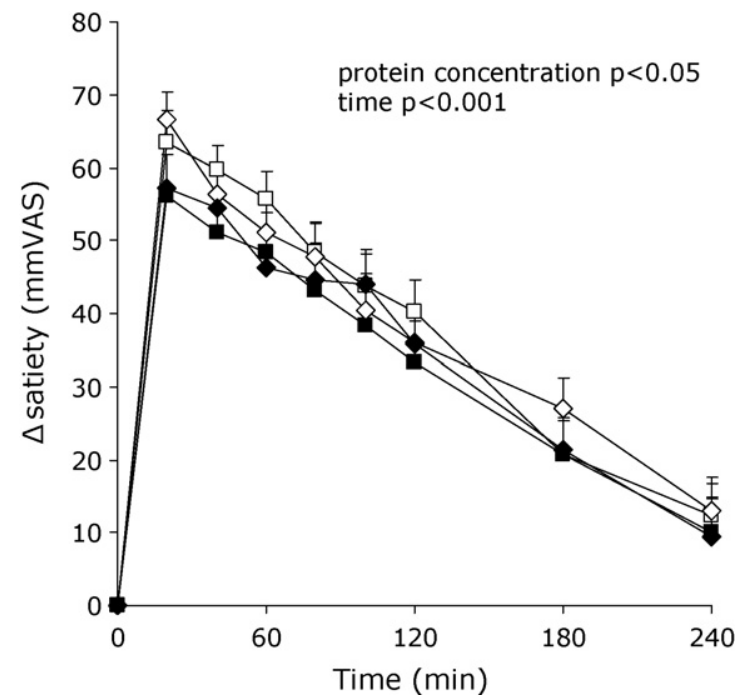

Fig. 1. Changes in satiety ratings (mmVAS) after a breakfast offered as a custard with either 10 En\% or 25 En\% from whey- or whey without GMP-protein expressed as delta compared to baseline in 25 subjects (men and women). Values are mean + S.E.M.: $(\square)$ whey $10 \%$, ( $\square$ ) whey $25 \%$, $(\diamond)$ whey without GMP $10 \%$, $(\diamond)$ whey without GMP 25\%. Three-way ANOVA with Fisher's PLSD post hoc correction for multiple comparisons showed an effect of protein concentration $(p<0.05)$ and time $(p<0.001)$ on satiety ratings (differences between all time points $(p<0.001)$, except for time point 20 and 40, 40 and 60, 60 and 80, 80 and 100 and 100 and 120). 


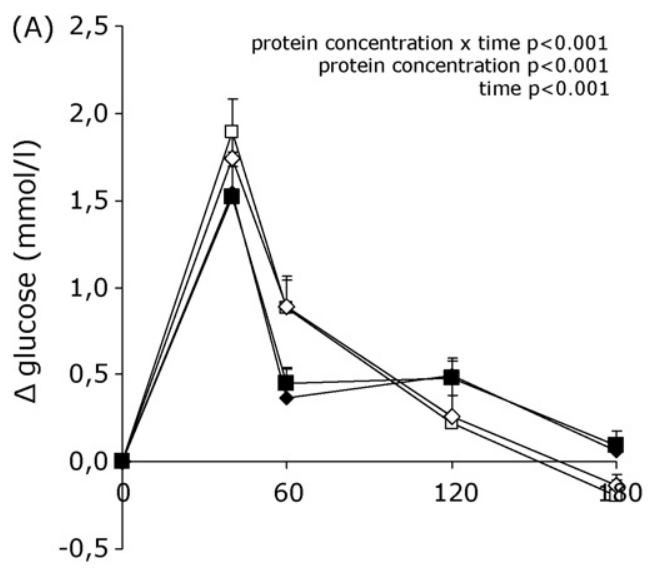

Time (min)

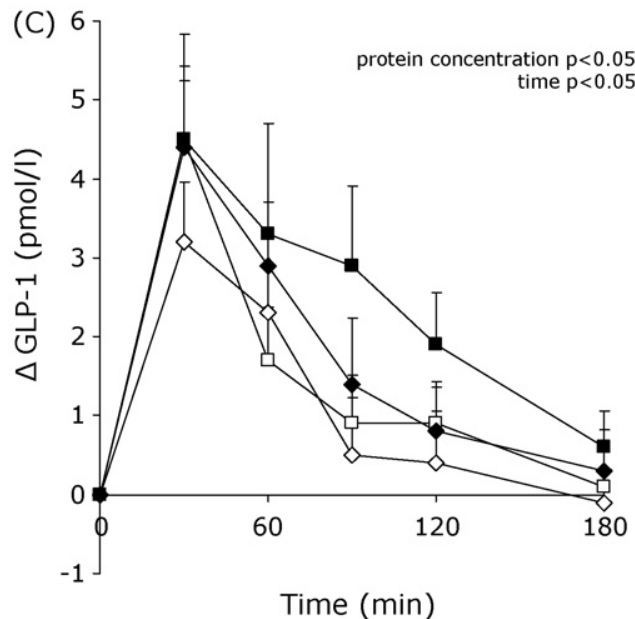

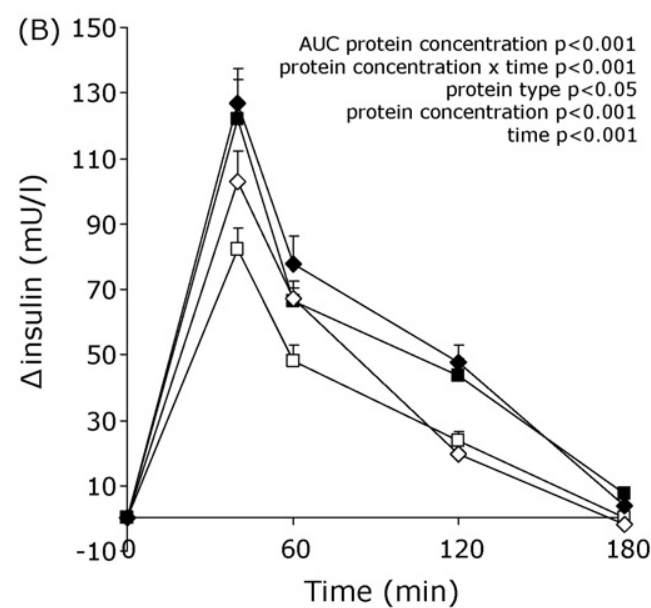

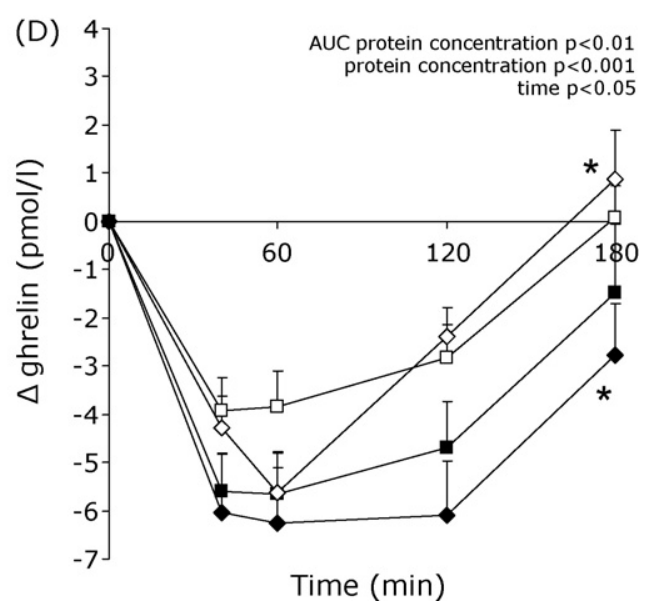

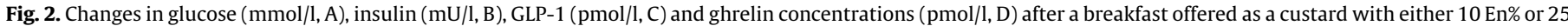

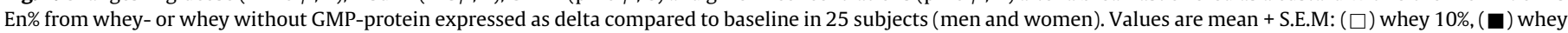

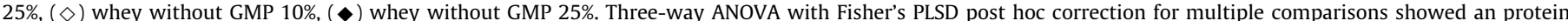

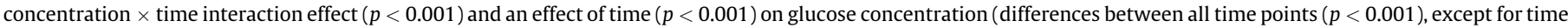

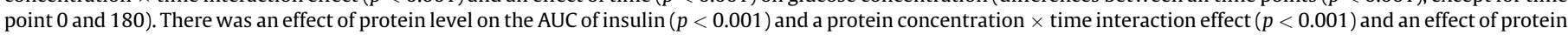

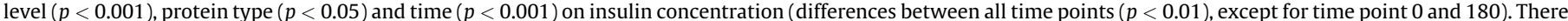

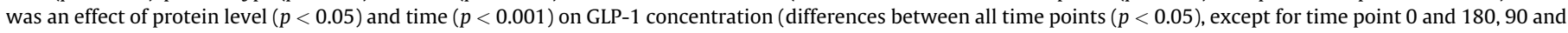

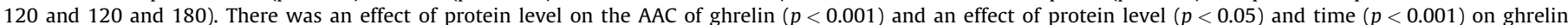

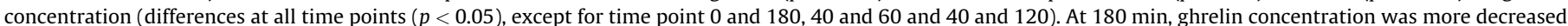
after whey without GMP $25 \%$ than after whey without GMP $10 \%\left({ }^{*} p<0.05\right)$.

With respect to changes in satiety ratings over time, there was no interaction effect of protein concentration $\times$ protein type $\times$ time. Moreover, there was no interaction effect of protein concentration $\times$ protein type, protein concentration $\times$ time or protein type $\times$ time. However, satiety ratings were more increased after a breakfast with $10 \%$ of energy from protein than after a breakfast with $25 \%$ of energy from protein $(p<0.05$, Fig. 1$)$ and were different between all time points ( $p<0.001$ all, Fig. 1 ), except for time point 20 and 40,40 and 60,60 and 80,80 and 100 and 100 and 120 . There was no effect of protein type.

\section{Glucose}

There was no interaction effect of protein concentration $x$ protein type on the glucose response expressed as AUC, and there were no effects of protein concentration or protein type on the AUC of glucose.

With respect to changes in glucose concentration over time, there was no interaction effect of protein concentration $\times$ protein type $\times$ time. Moreover, there was no interaction effect of protein concentration $\times$ protein type or protein type $\times$ time, whereas there was a protein concentration $\times$ time interaction effect $(p<0.001$, Fig. 2A). After the initial increase and subsequent decrease, glucose concentrations remained higher after a breakfast with $25 \%$ of energy from protein than after a breakfast with $10 \%$ of energy from protein $(p<0.001$, Fig. 2A). Furthermore, glucose concentrations were different between all time points ( $p<0.001$ all, Fig. 2A), except for time point 0 and 180 . There was no effect of protein type.

Insulin

There was no interaction effect of protein concentration $x$ protein type on the insulin response expressed as AUC, and there was no effect of protein type on the AUC of insulin. However, the insulin response was more increased after a breakfast with $25 \%$ of energy from protein than after a breakfast with $10 \%$ of energy from protein $(p<0.001)$.

With respect to changes in insulin concentration over time, there was no interaction effect of protein concentration $\times$ protein type $\times$ time. Moreover, there was no interaction effect of protein concentration $\times$ protein type or protein type $\times$ time, whereas there was a protein concentration $\times$ time interaction effect 
$(p<0.001$, Fig. 2B). Insulin concentrations increased more and decreased slower thereafter after a breakfast with $25 \%$ of energy from protein than after a breakfast with $10 \%$ of energy from protein $(p<0.001$, Fig. 2B). Insulin concentrations were more increased after a breakfast with $25 \%$ of energy from protein than after a breakfast with $10 \%$ of energy from protein $(p<0.001$, Fig. $2 \mathrm{~B})$ and were more increased after a breakfast with whey without GMP than after a breakfast with whey ( $p<0.05$, Fig. $2 \mathrm{~B})$. Furthermore, insulin concentrations were different between all time points $(p<0.001$ all, Fig. 2B), except for time point 0 compared with 180.

\section{$G L P-1$}

There was no interaction effect of protein concentration $\times$ protein type on the GLP-1 response expressed as AUC, and there were no effects of protein concentration or protein type on the AUC of GLP-1.

With respect to changes in GLP-1 concentration over time, there was no interaction effect of protein concentration $\times$ protein type $\times$ time. Moreover, there was no interaction effect of protein concentration $\times$ protein type, protein concentration $\times$ time or protein type $\times$ time. However, GLP-1 concentrations were more increased after a breakfast with $25 \%$ of energy from protein than after breakfast with $10 \%$ of energy from protein $(p<0.05$, Fig. 2C) and GLP1 concentrations were different between all time points ( $p<0.05$ all, Fig. 2C), except for time point 0 and 180,90 and 120 and 120 and 180.

Ghrelin

There was no interaction effect of protein concentration $x$ protein type on the ghrelin response expressed as AAC, and there was no effect of protein type on the AUC of ghrelin. However, the ghrelin response was more decreased after a breakfast with $25 \%$ of energy from protein than after a breakfast with $10 \%$ of energy from protein $(p<0.01)$

With respect to changes in ghrelin concentration over time, there was no interaction effect of protein concentration $\times$ protein type $\times$ time. Moreover, there was no interaction effect of protein concentration $\times$ protein type, protein concentration $\times$ time or protein type $\times$ time. However, ghrelin concentrations were more decreased after a breakfast with $25 \%$ of energy from protein than after a breakfast with $10 \%$ of energy from protein $(p<0.001$, Fig. 2D) and ghrelin concentrations were different between all time points ( $p<0.05$ all, Fig. 2D), except for time point 0 and 180,40 and 60 and 40 and 120

Analysis per time point revealed that ghrelin concentration was more decreased after a breakfast with $25 \%$ of energy from whey without GMP than after a breakfast with $10 \%$ of energy from whey without GMP at 180 min after breakfast $(p<0.05$, Fig. 2D).

\section{Amino acids}

There was a protein concentration $\times$ protein type interaction effect on the concentrations of glutamate $(p<0.01)$, threonine $(p<0.001)$, alpha-aminobutyric acid $(p<0.05)$, valine $(p<0.001)$, isoleucine $(p<0.001)$, branched-chain amino acids $(p<0.01)$, large neutral amino acids $(p<0.05)$ and sum amino acids $(p<0.05$, Table 3$)$.

Responses of all amino acids were more increased after a breakfast with $25 \%$ of energy from protein than after a breakfast with $10 \%$ of energy $(p<0.001$ all, Table 3$)$ except for glycine and taurine (Table 3$)$. Concentrations of serine $(p<0.01)$, threonine $(p<0.001)$, alanine $(p<0.01)$, alpha-aminobutyric acid $(p<0.01)$, and isoleucine $(p<0.001)$ were more increased after a breakfast with whey than after a breakfast with whey without GMP (Table 3 ), whereas concentrations of citrulline $(p<0.05)$, arginine $(p<0.01)$, tyrosine $(p<0.001)$, phenylalanine $(p<0.001)$, tryptophan $(p<0.001)$, leucine $(p<0.001)$, and lysine $(p<0.001)$ were more increased after a breakfast with whey without GMP than after a breakfast with whey (Table 3).

\section{Energy intake at lunch}

There was no interaction effect of protein type $\times$ session on energy intake at lunch. Mean energy intake at the first visit was $3125 \pm 162 \mathrm{~kJ}$ whereas on the fourth visit mean energy intake was

Table 3

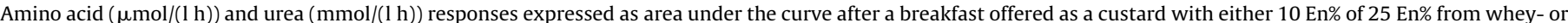
whey without GMP-protein in 25 subjects (men and women).

\begin{tabular}{|c|c|c|c|c|c|c|c|}
\hline & Whey $10 \%$ & Whey $25 \%$ & $\begin{array}{l}\text { Whey without } \\
\text { GMP } 10 \%\end{array}$ & $\begin{array}{l}\text { Whey without } \\
\text { GMP 25\% }\end{array}$ & $\begin{array}{l}p \text {-Value } \\
\text { concentration }\end{array}$ & $\begin{array}{l}p \text {-Value } \\
\text { type }\end{array}$ & $\begin{array}{l}p \text {-Value } \\
\text { interaction }\end{array}$ \\
\hline Glutamate & $-1,028 \pm 442$ & $3,705 \pm 517$ & $266 \pm 337$ & $2,163 \pm 381$ & 0.001 & 0.766 & 0.001 \\
\hline Asparagine & $3,925 \pm 337$ & $10,122 \pm 382$ & $3,977 \pm 313$ & $9,195 \pm 454$ & 0.001 & 0.237 & 0.187 \\
\hline Serine & $2,960 \pm 491$ & $9,178 \pm 889$ & $1,354 \pm 606$ & $6,038 \pm 743$ & 0.001 & 0.001 & 0.265 \\
\hline Glutamine & $2,220 \pm 1235$ & $12,156 \pm 1655$ & $1,800 \pm 1045$ & $7,146 \pm 1676$ & 0.001 & 0.055 & 0.104 \\
\hline Histidine & $832 \pm 248$ & $3,311 \pm 305$ & $1,418 \pm 360$ & $3,356 \pm 260$ & 0.001 & 0.280 & 0.355 \\
\hline Glycine & $-2,307 \pm 666$ & $-2,759 \pm 1044$ & $-2,346 \pm 663$ & $-4,686 \pm 914$ & 0.092 & 0.234 & 0.253 \\
\hline Threonine & $12,828 \pm 349$ & $34,393 \pm 1284$ & $8,484 \pm 588$ & $21,892 \pm 1154$ & 0.001 & 0.001 & 0.001 \\
\hline Citrulline & $-1,487 \pm 156$ & $-33 \pm 136$ & $-919 \pm 149$ & $203 \pm 116$ & 0.001 & 0.004 & 0.229 \\
\hline Arginine & $379 \pm 279$ & $5,327 \pm 404$ & $1,497 \pm 421$ & $6,292 \pm 309$ & 0.001 & 0.004 & 0.828 \\
\hline Alanine & $36,193 \pm 1383$ & $49,814 \pm 2859$ & $31,910 \pm 2111$ & $38,665 \pm 3059$ & 0.001 & 0.002 & 0.155 \\
\hline Taurine & $-131 \pm 80$ & $137 \pm 132$ & $-70 \pm 118$ & $-68 \pm 81$ & 0.194 & 0.487 & 0.198 \\
\hline Alpha-aminobutyric acid & $571 \pm 76$ & $1,262 \pm 111$ & $507 \pm 88$ & $793 \pm 96$ & 0.001 & 0.004 & 0.029 \\
\hline Tyrosine & $-205 \pm 174$ & $6,452 \pm 565$ & $1,973 \pm 373$ & $9,980 \pm 583$ & 0.001 & 0.001 & 0.133 \\
\hline Valine & $6,487 \pm 504$ & $34,006 \pm 1327$ & $6,786 \pm 1125$ & $24,916 \pm 1072$ & 0.001 & 0.001 & 0.001 \\
\hline Methionine & $868 \pm 224$ & $4,354 \pm 514$ & $1,319 \pm 171$ & $4,297 \pm 327$ & 0.001 & 0.549 & 0.442 \\
\hline Isoleucine & $9,387 \pm 303$ & $31,195 \pm 1133$ & $7,865 \pm 465$ & $22,388 \pm 1152$ & 0.001 & 0.001 & 0.001 \\
\hline Phenylalanine & $-178 \pm 123$ & $3,298 \pm 203$ & $1,193 \pm 280$ & $4,379 \pm 222$ & 0.001 & 0.001 & 0.492 \\
\hline Tryptophan & $1,558 \pm 180$ & $7,214 \pm 281$ & $3,241 \pm 145$ & $8,408 \pm 474$ & 0.001 & 0.001 & 0.407 \\
\hline Leucine & $10,219 \pm 373$ & $40,815 \pm 1502$ & $16,262 \pm 586$ & $46,428 \pm 2256$ & 0.001 & 0.001 & 0.877 \\
\hline Ornithine & $-700 \pm 1398$ & $3,390 \pm 382$ & $1,501 \pm 217$ & $2,967 \pm 267$ & 0.001 & 0.227 & 0.075 \\
\hline Lysine & $16,328 \pm 663$ & $43,270 \pm 1231$ & $20,146 \pm 909$ & $46,139 \pm 1996$ & 0.001 & 0.010 & 0.719 \\
\hline Branched-chain amino acids & $18,736 \pm 6020$ & $1,06,016 \pm 3703$ & $30,914 \pm 2087$ & $93,733 \pm 4377$ & 0.001 & 0.990 & 0.004 \\
\hline Large neutral amino acids & $25,709 \pm 1135$ & $1,15,766 \pm 4172$ & $34,080 \pm 2674$ & $1,08,092 \pm 4992$ & 0.001 & 0.240 & 0.044 \\
\hline Sum amino acids & $91,364 \pm 6611$ & $3,00,607 \pm 11430$ & $108,164 \pm 8655$ & $2,60,891 \pm 11934$ & 0.001 & 0.921 & 0.024 \\
\hline Urea & $-19 \pm 11$ & $119 \pm 11$ & $-23 \pm 14$ & $152 \pm 13$ & 0.001 & 0.226 & 0.126 \\
\hline
\end{tabular}

Values are means \pm S.E.M., $2 \times 2$ ANOVA for effects of protein concentration, protein type and interaction of protein concentration and protein type. 
$2974 \pm 179 \mathrm{~kJ}$ (ns). There was no interaction effect of protein concentration $\times$ protein type on energy intake at lunch, and there was no effect of protein concentration. However, protein type did have an effect on ad libitum energy intake at lunch. Energy intake at lunch was lower after a breakfast with whey than after a breakfast with whey without GMP $(2877 \pm 167$ versus $3208 \pm 180 \mathrm{~kJ}$, $p<0.05$ ).

\section{Discussion}

Ad libitum energy intake at lunch was $~ 10 \%$ lower after a breakfast with whey than after a breakfast with whey without GMP, irrespective of the protein concentration of the breakfast. The citrus-vanilla flavored custards were similar to custards widely available and often consumed in the Netherlands. It is therefore unlikely that unfamiliarity with the breakfasts influenced satiety responses. After being tested by a professional taste panel of NIZO Food Research, taste perception and hedonic values again were evaluated by the subjects and were excluded to affect appetite profile ratings differently. In the second set of experiments subjects underwent four sessions where energy intake was measured. These sessions were separated by at least 1 week and were fully randomized. There was no significant order effect; moreover, the study was single-blind and had a randomized design. Although changes in blood parameters and effects on subsequent energy intake were measured in two separate studies, both studies were conducted in the same subjects using the same breakfasts. Therefore, it would not be expected that the changes in blood parameters are different between the two studies.

GMP has many biological activities, for instance an increased pancreatic secretion of digestive peptides, and has been suggested to affect food intake regulation (Beucher, Levenez, Yvon, \& Corring, 1994; Brody, 2000; Pedersen et al., 2000; Yvon et al., 1994). However, GMP alone had no effect on subsequent energy intake or subjective indicators of satiety in an experiment with healthy humans consuming beverages with $0.4 \%$ or $2.0 \%$ GMP (Gustafson et al., 2001). Burton-Freeman reported that the presence or absence of GMP in whey offered as a preload had no remarkable effects on satiety, CCK release or food intake at a test meal (BurtonFreeman, 2008). Our results however show that GMP as part of whey-protein in a breakfast lowered subsequent energy intake at lunch with $\sim 10 \%$ compared with a breakfast with whey-protein without GMP. The absence of differences in satiety and food intake in the study of Burton-Freeman may be caused by the high protein content of the preload; $44 \%$ of energy from protein. Protein, that has been shown to be the most satiating macronutrient (Westerterp-Plantenga, Rolland, Wilson, \& Westerterp, 1999), at such a high level probably induces an elevated satiety response regardless of the presence or absence of GMP. Furthermore, the timing of the measurement of food intake is of major importance (Anderson et al., 2004) and may explain differences in results. A lunch test meal was provided to the subjects at 75 min after the preload; this time point was not underscored by appetite ratings, amino acid or hormone concentrations (Burton-Freeman, 2008). In the present study first the adequate moment in time was determined, using the same breakfasts, and appeared to be $180 \mathrm{~min}$ after the breakfast, based upon significant differences in ghrelin concentrations. Ghrelin has been suggested to play a physiological role in meal initiation in humans (Cummings et al., 2001). Differences in ghrelin concentrations may therefore result in differences in energy intake. Therefore, in the present study the choice of the moment in time to offer lunch was based on the latest time point where there were differences in ghrelin concentrations.

Several amino acids were increased more after the breakfast with whey than after the breakfast with whey without GMP regardless protein concentration, namely serine, threonine, alanine, alpha-aminobutyric acid and isoleucine. It may be hypothesized that these amino acids play a role in the reduction of food intake, what relates to the classic aminostatic theory from Mellinkoff that states that a rise in amino acid concentration is accompanied by a diminishing of appetite and that a subsequent increase of appetite is coincided with a fall in amino acid concentration (Mellinkoff, Frankland, Boyle, \& Greipel, 1956). Further research is needed to draw conclusions on a possible effect of serine, threonine, alanine, alpha-aminobutyric acid and isoleucine on energy intake. The differences in amino acid concentrations between whey and whey without GMP reflect the differences in amino acid composition of the breakfasts and support the difference in energy intake at lunch at $180 \mathrm{~min}$ after breakfast.

With respect to the effects of a high and normal amount of protein relatively larger increases in insulin and GLP-1 and larger decreases in ghrelin concentrations appeared after a breakfast with $25 \%$ of energy from whey-protein than after a breakfast with $10 \%$ of energy. So a breakfast with a high amount of whey-protein showed stronger physiological responses in terms of orexigenic or anorexigenic hormones. Yet, this did not translate into satiety or food intake effects. A mathematical uncoupling of increases in 'satiety' or 'hunger' hormone concentrations and the satiety effect took place. The observed increased satiety after a breakfast with $10 \%$ of energy from protein compared with a breakfast with $25 \%$ of energy from protein was rather unexpected since previously, high protein meals have been shown to be more satiating than normal protein meals (Westerterp-Plantenga et al., 2006). An explanation for this increased satiety may be the increased glucose concentrations in the early postprandial phase after a breakfast with $10 \%$ of energy from protein compared with after a breakfast with $25 \%$ of energy from protein. It has been hypothesized earlier that satiety is more increased with higher glucose concentrations (Anderson et al., 2004).

A meal higher in protein content induced an increased insulin response as compared with a meal with less protein but the same carbohydrate content (Nuttall, Mooradian, Gannon, Billington, \& Krezowski, 1984). Accordingly, increases in insulin concentration were larger after the high than the normal whey-protein breakfast. The larger increase in GLP-1 after a breakfast with 25\% of energy from whey-protein can be explained by the recent finding that whey-protein inhibits dipeptidyl peptidase IV activity, the enzyme breaking down GLP-1, thus prolonging the action of GLP-1 (Gunnarsson et al., 2006). The postprandial ghrelin suppression was increased after a breakfast with $25 \%$ of energy from protein, which is in line with previous studies that showed that insulin can suppress ghrelin and that insulin decreases the duration of the postprandial ghrelin suppression (Cummings, Foster-Schubert, \& Overduin, 2005; Hagemann et al., 2007).

In conclusion, GMP as a whey-fraction reduced energy intake, irrespective of the protein content of the breakfast, coinciding with increased concentrations of certain amino acids (serine, threonine, alanine, alpha-aminobutyric acid, valine and isoleucine). Although between different concentrations of whey-protein significant differences in hormone responses were present, these were not related to effects on satiety ratings or energy intake.

\section{Acknowledgement}

This study was funded by the Top Institute Food and Nutrition, The Netherlands.

\section{References}

Adam, T. C., \& Westerterp-Plantenga, M. S. (2005). Nutrient-stimulated GLP-1 release in normal-weight men and women. Hormone and Metabolic Research, 37, 111-117. 
Anderson, G. H., Tecimer, S. N., Shah, D., \& Zafar, T. A. (2004). Protein source, quantity, and time of consumption determine the effect of proteins on short-term food intake in young men. Journal of Nutrition, 134, 3011-3015.

Beucher, S., Levenez, F., Yvon, M., \& Corring, T. (1994). Effects of gastric digestive products from casein on CCK release by intestinal cells in rat. Journal of Nutritional Biochemistry, 5, 578-584.

Boirie, Y., Dangin, M., Gachon, P., Vasson, M. P., Maubois, J. L., \& Beaufrere, B. (1997). Slow and fast dietary proteins differently modulate postprandial protein accretion. Proceedings of the National Academy of Sciences of the United States of America, 94, 14930-14935.

Brody, E. P. (2000). Biological activities of bovine glycomacropeptide. The British Journal of Nutrition, 84(Suppl. 1), S39-46.

Burton-Freeman, B. M. (2008). Glycomacropeptide (GMP) is not critical to wheyinduced satiety, but may have a unique role in energy intake regulation through cholecystokinin (CCK). Physiology \& Behavior, 93, 379-387.

Cummings, D. E., Foster-Schubert, K. E., \& Overduin, J. (2005). Ghrelin and energy balance: focus on current controversies. Current Drug Targets, 6, 153-169.

Cummings, D. E., Purnell, J. Q., Frayo, R. S., Schmidova, K., Wisse, B. E., \& Weigle, D. S. (2001). A preprandial rise in plasma ghrelin levels suggests a role in meal initiation in humans. Diabetes, 50, 1714-1719.

Dangin, M., Boirie, Y., Garcia-Rodenas, C., Gachon, P., Fauquant, J., Callier, P., et al. (2001). The digestion rate of protein is an independent regulating factor of postprandial protein retention. American Journal of Physiology-Endocrinology and Metabolism, 280, E340-348.

Dangin, M., Boirie, Y., Guillet, C., \& Beaufrere, B. (2002). Influence of the protein digestion rate on protein turnover in young and elderly subjects. Journal of Nutrition, 132, 3228S-3233S.

Gunnarsson, P. T., Winzell, M. S., Deacon, C. F., Larsen, M. O., Jelic, K., Carr, R. D., et al. (2006). Glucose-induced incretin hormone release and inactivation are differently modulated by oral fat and protein in mice. Endocrinology, 147, 3173-3180.

Gustafson, D. R., McMahon, D. J., Morrey, J., \& Nan, R. (2001). Appetite is not influenced by a unique milk peptide: caseinomacropeptide (CMP). Appetite, 36, 157-163.

Hagemann, D., Holst, J. J., Gethmann, A., Banasch, M., Schmidt, W. E., \& Meier, J. J. (2007). Glucagon-like peptide 1 (GLP-1)suppresses ghrelin levels in humans via increased insulin secretion. Regulatory peptides, 143(1-3), 64-68.

Hall, W. L., Millward, D. J., Long, S. J., \& Morgan, L. M. (2003). Casein and whey exert different effects on plasma amino acid profiles, gastrointestinal hormone secretion and appetite. The British Journal of Nutrition, 89, 239-248.

Harris, J. A., \& Benedict, F. G. (1918). A biometric study of basal metabolism in man. Proc Natl Acad Sci, 4, 370-373.

Lejeune, M. P., Kovacs, E. M., \& Westerterp-Plantenga, M. S. (2005). Additional protein intake limits weight regain after weight loss in humans. The British Journal of Nutrition, 93, 281-289.

Luhovyy, B. L., Akhavan, T., \& Anderson, G. H. (2007). Whey proteins in the regulation of food intake and satiety. Journal of the American College of Nutrition, 26, 704S-712S.

Marshall, K. (2004). Therapeutic applications of whey protein. Alternative Medicine Review, 9, 136-156.

Mellinkoff, S. M., Frankland, M., Boyle, D., \& Greipel, M. (1956). Relationship between serum amino acid concentration and fluctuations in appetite. Journal of Applied Physiology, 8, 535-538.

Morifuji, M., Sakai, K., \& Sugiura, K. (2005). Dietary whey protein modulates liver glycogen level and glycoregulatory enzyme activities in exercise-trained rats. Experimental Biology and Medicine (Maywood), 230, 23-30.
Munro, H. N. (1976). Second Boyd Orr memorial lecture. Regulation of body protein metabolism in relation to diet. The Proceedings of the Nutrition Society, 35, 297-308.

Nuttall, F. Q., Mooradian, A. D., Gannon, M. C., Billington, C., \& Krezowski, P. (1984). Effect of protein ingestion on the glucose and insulin response to a standardized oral glucose load. Diabetes Care, 7, 465-470.

Pedersen, N. L., Nagain-Domaine, C., Mahe, S., Chariot, J., Roze, C., \& Tome, D. (2000). Caseinomacropeptide specifically stimulates exocrine pancreatic secretion in the anesthetized rat. Peptides, 21, 1527-1535.

Pi-Sunyer, F. X. (1993). Medical hazards of obesity. Annals of Internal Medicine, 119, $655-660$.

Seidell, J. C. (1995). Obesity in Europe. Obesity Research, 3(Suppl. 2), 89s-93s.

Senn, S. (2006). Cross-over trials in Statistics in Medicine: the first '25' years. Statistics in Medicine, 25, 3430-3442.

Skov, A. R., Toubro, S., Ronn, B., Holm, L., \& Astrup, A. (1999). Randomized trial on protein vs carbohydrate in ad libitum fat reduced diet for the treatment of obesity. International Journal of Obesity and Related Metabolic Disorders, 23, 528-536.

Spaaij, C. J., \& Pijls, L. T. (2004). New dietary reference intakes in the Netherlands for energy, proteins, fats and digestible carbohydrates. European Journal of Clinical Nutrition, 58, 191-194.

Stubbs, R. J., Hughes, D. A., Johnstone, A. M., Rowley, E., Reid, C., Elia, M., et al. (2000). The use of visual analogue scales to assess motivation to eat in human subjects: a review of their reliability and validity with an evaluation of new hand-held computerized systems for temporal tracking of appetite ratings. The British Journal of Nutrition, 84, 405-415.

Stunkard, A. J., \& Messick, S. (1985). The three-factor eating questionnaire to measure dietary restraint, disinhibition and hunger. Journal of Psychosomatic Research, 29, 71-83.

van Eijk, H. M., Rooyakkers, D. R., \& Deutz, N. E. (1993). Rapid routine determination of amino acids in plasma by high-performance liquid chromatography with a 2-3 microns Spherisorb ODS II column. Journal of Chromatography, 620, $143-148$.

Weigle, D. S., Breen, P. A., Matthys, C. C., Callahan, H. S., Meeuws, K. E., Burden, V. R., et al. (2005). A high-protein diet induces sustained reductions in appetite, ad libitum caloric intake, and body weight despite compensatory changes in diurnal plasma leptin and ghrelin concentrations. American Journal of Clinical Nutrition, 82, 41-48.

Westerterp-Plantenga, M. S., Luscombe-Marsh, N., Lejeune, M. P., Diepvens, K., Nieuwenhuizen, A., Engelen, M. P., et al. (2006). Dietary protein, metabolism, and bodyweight regulation: dose-response effects. International Journal of Obesity (London), 30(Suppl. 3), S16-S23.

Westerterp-Plantenga, M. S., Rolland, V., Wilson, S. A., \& Westerterp, K. R. (1999a). Satiety related to $24 \mathrm{~h}$ diet-induced thermogenesis during high protein/carbohydrate vs high fat diets measured in a respiration chamber. European Journal of Clinical Nutrition, 53, 495-502.

Westerterp-Plantenga, M. S., Westerterp, K. R., Rubbens, M., Verwegen, C. R., Richelet, J. P., \& Gardette, B. (1999b). Appetite at "high altitude" [Operation Everest II (Comex-'97)]: a simulated ascent of Mount Everest. Journal of Applied Physiology, $87,391-399$

Westerterp, K. R., \& Kester, A. D. (2003). Physical activity in confined conditions as an indicator of free-living physical activity. Obesity Research, 11, 865-868.

Yvon, M., Beucher, S., Guilloteau, P., Le Huerou-Luron, I., \& Corring, T. (1994). Effects of caseinomacropeptide (CMP) on digestion regulation. Reproduction Nutrition Development, 34, 527-537. 